\title{
The Effects Of Information Technology Innovativeness On Audit Efficiencies
}

\author{
Lorraine Lee, University of North Carolina Wilmington, USA \\ James Whitworth, University of South Florida, USA \\ Susan Hermanson, University of North Carolina Wilmington, USA
}

\begin{abstract}
Information technology (IT) has been identified as an important component of a company's internal control and general business environment (COSO 2009). This paper examines how IT innovativeness can create value in the accounting domain through its role in improving efficiencies associated with the audit process by reducing overall inherent risks and business risks. To test the relationship between IT innovativeness and audit efficiencies, we use a sample of IT firms recognized by the publication InformationWeek as innovative users of IT and compare those firms with a control group. For the dependent variables measuring audit efficiencies, we focus on audit fees and audit delays. Our research suggests that firms recognized as IT innovators pay lower audit fees and receive their audit reports in a timelier manner than the control firms. Our results are consistent with the idea that investments in IT can provide significant benefits for firms in terms of audit efficiencies.
\end{abstract}

Keywords: Innovative IT; IT Value; Audit Fees; Audit Delays

\section{INTRODUCTION}

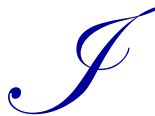

nformation technology (IT) innovativeness has been recognized for its role in creating value in firms through productivity enhancements (Hitt and Brynjolfsson 1996), improving inter-organizational relationships (Rai et al. 2006), and improving intermediate processes (Devaraj and Kohli 2003). For intermediate processes, IT innovativeness has traditionally been associated with areas such as business process reengineering (Davenport 1993) and supply chain efficiencies (Dehning et al. 2007). However, less research has focused on the impact of IT innovativeness on the support and administrative processes within a firm, such as accounting-related activities (Masli et al. 2011).

This paper answers the call by Masli et al. (2011) to expand research in the area of IT value and accounting-related processes. Researchers have started this initiative by examining such areas as the role of IT in facilitating the timely release of earnings reports (Brazel and Dang 2008) and the impact of IT on internal controls (Masli et al. 2010; Klamm and Weidenmier 2009). The purpose of this paper is to extend this line of research by examining how IT innovativeness can create value in the accounting domain through its role in improving efficiencies associated with the audit process.

Since the enactment of the Sarbanes-Oxley Act of 2002 (SOX), public companies have faced greater pressure and costs for assuring the effectiveness of their systems of internal control over financial reporting. SOX requires documentation, testing, and improvements of a company's internal control, auditing, and financial reporting systems. Given the importance of IT in improving the administration of a firm, this study examines the relationship between IT innovativeness and improvements in audit efficiency.

To test the relationship between IT innovativeness and audit efficiencies, we use a sample of IT firms recognized by the publication InformationWeek as innovative users of IT and compare those firms with a control group over a three year period covering Compustat fiscal years 2004-2006. For the dependent variables measuring audit efficiencies, we focus on audit fees (Krishnan et al. 2011) and audit delays (Ettredge et al. 2006). Our research 
suggests that innovative IT firms pay lower audit fees and that the results of their audit are filed with the SEC sooner than their matched counterparts, consistent with IT innovativeness improving audit efficiencies.

This paper is organized as follows. First, we provide background literature and hypotheses development related to IT innovativeness and audit efficiencies. Next, we discuss the research methodology and data selection. We then present the results of the data analysis and conclude with a discussion of the findings, the limitations, and areas for future research.

\section{BACKGROUND AND HYPOTHESES}

\subsection{IT Innovativeness}

Earlier research in the area of strategic IT has associated innovativeness in IT with the transformation of an organization through fundamentally redefining business processes and relationships (Zuboff 1988). IT innovativeness has been associated with the use of IT to introduce radical business models that disrupt firm practices, such as the case of internet computing in systems development organizations (Lyytinen and Rose 2003) or the digitization of information that can intra- and inter-organizationally tie activities and processes together (Sambamurthy et al. 2003).

An IT innovation is defined as a digital and/or communication technology that permeates throughout an organization through its integration with a complex network of interrelated technologies and processes (Swanson 1994). Innovative IT is synonymous with IT excellence in that companies characterized as innovative have used IT to create competitive advantage, improve relationships with customers and suppliers, and optimize internal and external business processes (e.g. Friedenberg 2012).

One specific business process that IT can impact is the overall system of internal controls within a company. IT is responsible for the development of both operational and financial reports that manage and control the organization. In fact, the Committee of Sponsoring Organizations (COSO) 2009 positions IT at the very core of a system of effective internal controls over financial reporting, with effective internal control monitoring via IT leading to effective internal control processes, which then leads to effective assurances over those processes (Masli et al. 2010). Prior literature has documented that weak internal controls are recognized by the capital market in the form of a higher cost of equity (Ashbaugh-Skaife et al. 2009, Lambert et al. 2007). Weak internal controls are also associated with less accurate management earnings forecasts and less reliable output from the firm's financial reporting system ( $\mathrm{Li}$ et al. 2012).

Firms may implement internal control monitoring technology in order to minimize control risks. Control risk is the likelihood that the control structure of a firm is flawed because controls are either absent or inadequate to prevent or detect errors (Hall 2011). With internal control monitoring technology, firms can review their compliance efforts, identify potential and actual problems, and proactively deter and detect fraud (Brunemeister et al. 2007). Information technology, specifically control monitoring software, has been associated with lower likelihood of material weaknesses, smaller increase in audit fees, and smaller increases in audit delays (Masli et al. 2010).

However, control risk is not the only component of risk in organizations. Inherent risks are those risks associated with the unique characteristics of the business or industry (Institute of Internal Auditors, 1978), while business risks are the risks associated with a firm in not achieving its objectives (COSO 2009). Firms with innovative IT are able to obtain information for internal decision making that is both higher quality (more integrated and less uncertain) and more timely, potentially leading to long-term competitive advantages (Dos Santos and Peffers 1995). This suggests that there may be less inherent and business risks in these firms, which can also lead to lower audit fees and audit delays. Or in other words, IT can impact an audit not only by reducing control risks through better controls monitoring, as Masli et al. 2010 suggest, but also through reducing inherent risks and business risks through better firm-level information quality as evident through the innovative use of IT. 
With the recognition of the importance of IT in reducing control risks, as well as reducing business and inherent risks, this paper investigates the relationship between IT innovativeness and the audit process in terms of audit efficiency. We focus on two variables of interest to investigate whether IT innovativeness is associated with improved audit efficiency: audit fees and audit delay.

\subsection{Audit Fees}

Prior research has found that audit fees are positively associated with various measures of client size, complexity and risk (Simunic 1980, Palmrose 1986, Francis \& Simon 1987, O'Keefe et al. 1994, Hay et al. 2006). Other studies have investigated audit fee differences associated with auditor or board characteristics (Ferguson and Stokes 2002, Carcello et al. 2002, Casterella et al 2004, Francis et al. 2005).

Particularly relevant to our study is the recent prior literature examining the association between audit fees and weak internal controls. These studies (Hogan and Wilkins 2008, Raghunandan and Rama 2006, and Hoitash et al. 2008) find that weak internal controls, measured by SOX 302 and SOX 404 internal control material weakness disclosures, are associated with larger audit fees post-SOX ${ }^{1}$. These comparisons are in effect showing that relative to the baseline group of firms without reportable internal control weaknesses, firms with internal control weaknesses pay a higher audit fee. This may be due to the increased audit effort (more substantive testing, etc.) necessary to achieve the predetermined acceptable risk level while compensating for decreased reliance on the firm's internal controls.

Linking the above to IT components directly, Klamm and Watson (2009) find that companies with weak IT components have been found to report more material weaknesses and misstatements than firms without the ITrelated weaknesses. Our conjecture is that firms with innovative IT have made substantial investments in the quality of their information systems, potentially resulting in improved controls and administrative processes. Strong IT components may then permit the auditor to place greater reliance on them, decreasing the amount of substantive testing and related audit work necessary by auditors to achieve the predetermined acceptable risk level.

In terms of control risk, prior literature (Masli et al. 2010) has found an association between internal control monitoring software and lower audit fees. Business risk, on the other hand, deals with the risk that a business will not achieve its strategic plan, i.e. its ability to meet its goals and objectives. Companies recognized for IT innovativeness are likely to be companies whose IT strategy is aligned with their strategic plan (Sabherwal and Chan 2001), thereby reducing business risk. Since external auditors typically use a risk-based approach to auditing, any reduction in business risk should correlate to lower audit fees. Therefore, we expect the following:

H1: Firms recognized as being innovative users of IT will have lower audit fees than firms in the control group.

\subsection{Audit Delay}

Audit delay, also referred to as the audit report lag, is the number of calendar days between a company's fiscal year end and its audit report date (Ashton et al. 1987, Knechel and Payne 2001, Bronson et al. 2011).Because a company's annual financial statement information cannot be filed with the SEC prior to the audit report date, a shorter audit delay is preferred to a longer one, since the information value of the financial information is known to deteriorate over time (Ashton et al. 1987,Delaney et al. 1997, Knechel and Payne 2001, Leventis et al. 2005). Hence, a longer audit delay is associated with lower information value and a shorter delay is associated with higher information value (Delaney et al. 1997).

Audit delay has been investigated in a number of research studies, including Ashton et al.1987, Ashton et al. 1989, Newton and Ashton 1989, Bamber et al. 1993, Schwartz and Soo 1996, Knechel and Payne 2001, Leventis et al. 2005. While these studies investigated a variety of accounting and auditing factors associated with audit delay, our study focuses on the impact of IT innovativeness on audit delay.

\footnotetext{
${ }^{1}$ They also note that audit fees increased across the board post-SOX, but that firms disclosing an internal control material weakness paid an additional premium.
} 
Given prior findings of IT's association with more timely release of earnings reports (Brazel and Dang 2008) and improved internal controls (Masli et al. 2010; Klamm and Weidenmier 2009), we posit that such benefits will tie in to shorter audits. If controls are improved due to better, more innovative IT systems, audit work should decrease due to greater reliance on controls, and audit delay should be reduced as compared to firms who are not innovative with respect to IT. In the audit literature, material weaknesses in internal control are associated with longer audit delay, and total engagement hours have been found to be positively correlated with audit delay (the more hours worked on an audit, the longer the delay). Therefore, stronger internal controls that result from the firm's investment in innovative IT may lead to a more efficient audit, resulting in a shorter audit delay. Similarly innovative IT can reduce overall business risks and inherent risks, resulting in fewer high risk areas to audit and requiring fewer hours to complete the audit. Therefore, we hypothesize:

H2: Firms recognized as being innovative users of IT will experience shorter audit delays than firms in the control group.

\section{RESEARCH DESIGN}

\subsection{Sample}

The list of innovative IT companies is from InformationWeek, a publication that annually recognizes the top 500 innovative organizations with regard to their IT practices and strategies. Other studies (e.g. Kobelsky et al. 2008; Henderson et al. 2010) have used IT expenditure data associated with the InformationWeek rankings. In this study, our sample is comprised of the public companies recognized on the InformationWeek 500 list from 2005. We matched each public company from the InformationWeek 500 list with another public company based on industry (NAICS code) and total revenue. The other variables of interest are obtained from the Audit Analytics and Compustat databases. In Table 1 we provide details on our sample selection.

Table 1. Sample Selection

\begin{tabular}{lc}
\hline & Number of firms \\
\hline Firms in Information Week's Top 500 list & 500 \\
\hline Less: & $(17)$ \\
Companies not in Audit Analytics & $(222)$ \\
Companies not in Compustat & $(67)$ \\
Companies with missing required data items & 194 \\
Total & $(27)$ \\
\hline Companies matched to private companies, ADR's, or LLCs & $(30)$ \\
Companies without a good match & $(30)$ \\
Companies whose match is missing required data items for all years & 107 \\
\hline
\end{tabular}

Our final sample includes a group of 107 companies identified by Information Week as innovative in information technology and 107 control companies matched by size and industry. We examine the Compustat company-years 2004 through 2006 for those 214 companies, resulting in a final sample of 580 company-years.

\subsection{Models and Methods}

To test our hypotheses that IT innovativeness will impact the company's audit fees and the speed with which the audit is completed, we consider two similar models based on prior literature. All variable definitions are formally presented in the appendix. Both of our dependent variables are transformed via the natural $\log$, as both audit delay and audit fees are positively skewed (Krishnan and Yang 2009). The audit fee model (model 1) is wellestablished in archival audit literature (Francis et al. 2005, Krishnan et al. 2011) and explains a large amount of the variation in audit fees: 


$$
\begin{aligned}
& \text { Fees }=\beta_{0}+\beta_{1} * \text { IT }+\beta_{2} * \text { Seg }+\beta_{3} * \text { B } 4+\beta_{4} * \text { Size }+\beta_{5} * \text { MB }+\beta_{6} * \text { Rec }+\beta_{7} * \text { Roa }+\beta_{8} * \\
& \text { RoaNeg }+\beta_{9} * \text { Lev }+\beta_{10} * \text { Spec }+\beta_{11} * \text { Foreign }+\beta_{12} * \text { MW }+\beta_{13} * \text { Restruc }+\beta_{14} * \text { Merger } \\
& +\beta_{15} * \text { Busy }+\beta_{16} * \text { GC }+ \text { industry fixed-effects }+ \text { year fixed-effects }+\mathrm{e}
\end{aligned}
$$

The dependent variable in model 1 is the natural log of audit fees paid by the company, which is consistent with prior audit fee research (Francis et al. 2005, Ferguson et al. 2003, Krishnan et al. 2011). Our variable of interest is IT, a dummy equal to one for companies listed on the InformationWeek 500. Audit fees typically increase with almost all of our other explanatory variables, including firm size (Size), complexity (Seg, Foreign), use of a Big 4 auditor (B4), a nonstandard audit report (going concern - GC, material weakness - MW), receivables level (Rec), larger Market-to-Book ratio (MB) and leverage (Lev), disclosure of special items (Spec), December fiscal-year end (Busy), and restructuring or merger activity (Merger, Restruc). Company profitability is generally associated with smaller audit fees (Roa), while loss firms may face larger audit fees (RoaNeg).

Our second model considers the number of days from company fiscal-year end until the audit report date, and uses several of the same control variables as model 1 :

$$
\begin{aligned}
& \text { Delay }=\beta_{0}+\beta_{1} * \mathrm{IT}+\beta_{2} * \operatorname{Seg}+\beta_{3} * \mathrm{~B} 4+\beta_{4} * \text { Size }+\beta_{5} * \mathrm{MB}+\beta_{6} * \operatorname{Rec}+\beta_{7} * \text { Roa }+\beta_{8} * \\
& \text { RoaNeg }+\beta_{9} * \text { Lev }+\beta_{10} * \text { Spec }+\beta_{11} * \text { Foreign }+\beta_{12} * \text { MW }+\beta_{13} * \text { Restruc }+\beta_{14} * \text { Merger }+ \\
& \beta_{15} * \text { Busy }+\beta_{16} * \text { LAF }+\beta_{17} * \mathrm{AF}+\beta_{18} * \text { GC }+\beta_{19} * \text { ScaledFees }+ \text { industry fixed-effects }+ \\
& \text { year fixed-effects }+\mathrm{e} \\
& \text { (EQN2) }
\end{aligned}
$$

The dependent variable in model 2 is the natural log of the number of days between the company's fiscal-year end and the audit report date. IT remains our variable of interest. We add LAF, AF, and ScaledFees to model 1 to control for companies' 10-K filing status and the difficulty of the company to audit (as measured by audit fees scaled by total assets, Ettredge et al. 2006).

\section{RESULTS}

\subsection{Descriptive Statistics}

Descriptive statistics for our matched sample are presented in Table 2. We winsorize all variable values at the first and $99^{\text {th }}$ percentile. Due to the matched nature of our sample, the test firms and control firms do not differ significantly for most of our variables. The average audit delay in our sample is just over 63 days, which is consistent with prior literature (Bronson et al. 2011). The average audit fee is slightly under $\$ 3.4$ million. Additionally, we provide a Pearson correlation matrix in panel B of Table 2. Per the correlation matrix, IT is negatively associated with audit delay (-.11) at a statistically significant level. IT is negatively associated with audit fees as well (-.03), but not at a statistically significant level. 
Table 2. Descriptive Statistics and Correlation Matrix

\begin{tabular}{|c|c|c|c|c|c|}
\hline \multicolumn{6}{|c|}{ Panel A: Descriptive statistics } \\
\hline Variable & Mean & StdDev & Q1 & Median & Q3 \\
\hline Delay & 4.1444 & 0.3703 & 4.0073 & 4.0944 & 4.4285 \\
\hline Fees & 15.0384 & 0.9009 & 14.4138 & 15.0861 & 15.6695 \\
\hline IT & 0.5077 & 0.5004 & 0 & 1 & 1 \\
\hline Seg & 1.6764 & 0.6719 & 1.3863 & 1.7918 & 2.0794 \\
\hline $\mathrm{B} 4$ & 0.9725 & 0.1638 & 1 & 1 & 1 \\
\hline Size & 8.5738 & 1.3992 & 7.4838 & 8.4422 & 9.6924 \\
\hline MB & 3.1969 & 2.3416 & 1.7865 & 2.5147 & 3.8373 \\
\hline $\operatorname{Rec}$ & 0.2633 & 0.1894 & 0.1247 & 0.2176 & 0.3320 \\
\hline Roa & 0.0570 & 0.0518 & 0.0265 & 0.0504 & 0.0837 \\
\hline RoaNeg & 0.0551 & 0.2283 & 0 & 0 & 0 \\
\hline Lev & 0.5985 & 0.1886 & 0.4561 & 0.6054 & 0.7438 \\
\hline Spec & 0.7849 & 0.4113 & 1 & 1 & 1 \\
\hline Foreign & 0.2461 & 0.4311 & 0 & 0 & 0 \\
\hline MW & 0.0310 & 0.1734 & 0 & 0 & 0 \\
\hline Restruc & 0.4441 & 0.4973 & 0 & 0 & 1 \\
\hline Merger & 0.0826 & 0.2755 & 0 & 0 & 0 \\
\hline Busy & 0.6816 & 0.4663 & 0 & 1 & 1 \\
\hline LAF & 0.7849 & 0.4113 & 1 & 1 & 1 \\
\hline $\mathrm{AF}$ & 0.1704 & 0.3763 & 0 & 0 & 0 \\
\hline ScaledFees & 0.0105 & 0.0106 & 0.0033 & 0.0072 & 0.0138 \\
\hline GC & 0.0034 & 0.0586 & 0 & 0 & 0 \\
\hline
\end{tabular}

Descriptive statistics for the full sample of 580 company-years, comprised of 107 companies identified by Information Week as being innovative in information technology and 107 control companies for the Compustat fiscal years 2004-2006. Two-sided univariate tests of means suggest differences between the test group (IT=1) and control group (IT=0) at the one percent (five percent) ((ten percent)) level for the variables Delay and ScaledFees (LAF) ((For)). Two-sided univariate tests of medians provide qualitatively similar results. Variable definitions are provided in the appendix. 
(Table 2 continued)

Panel B: Pearson Correlation Matrix

\begin{tabular}{|c|c|c|c|c|c|c|c|c|c|c|c|c|c|c|c|c|c|c|c|c|}
\hline & IT & Seg & B4 & Size & MB & Rec & Roa & $\begin{array}{l}\text { Roa } \\
\text { Neg }\end{array}$ & Lev & Spec & Foreign & MW & Restruc & Merger & Busy & LAF & $\mathbf{A F}$ & $\begin{array}{c}\text { Scaled } \\
\text { Fees }\end{array}$ & GC & Fees \\
\hline Seg & 0.01 & & & & & & & & & & & & & & & & & & & \\
\hline B4 & 0.04 & 0.05 & & & & & & & & & & & & & & & & & & \\
\hline Size & 0.06 & 0.06 & 0.16 & & & & & & & & & & & & & & & & & \\
\hline MB & -0.07 & 0.08 & 0.01 & -0.03 & & & & & & & & & & & & & & & & \\
\hline $\operatorname{Rec}$ & -0.02 & -0.24 & 0.08 & -0.02 & -0.03 & & & & & & & & & & & & & & & \\
\hline Roa & 0.00 & 0.11 & 0.01 & -0.04 & 0.44 & -0.10 & & & & & & & & & & & & & & \\
\hline RoaNeg & 0.04 & -0.01 & 0.04 & -0.08 & -0.03 & 0.00 & -0.51 & & & & & & & & & & & & & \\
\hline Lev & 0.04 & -0.09 & 0.01 & 0.39 & 0.13 & 0.17 & -0.44 & 0.18 & & & & & & & & & & & & \\
\hline Spec & -0.03 & 0.15 & -0.04 & -0.04 & 0.06 & 0.00 & -0.01 & 0.03 & -0.05 & & & & & & & & & & & \\
\hline Foreign & -0.08 & 0.20 & 0.05 & 0.02 & 0.11 & -0.02 & -0.02 & 0.09 & 0.03 & 0.18 & & & & & & & & & & \\
\hline MW & -0.04 & 0.09 & 0.03 & 0.01 & 0.02 & 0.10 & -0.11 & 0.04 & 0.08 & -0.03 & 0.08 & & & & & & & & & \\
\hline Restruc & 0.04 & 0.28 & 0.00 & -0.16 & 0.05 & 0.01 & -0.05 & 0.07 & -0.05 & 0.43 & 0.25 & -0.02 & & & & & & & & \\
\hline Merger & -0.02 & 0.01 & -0.06 & 0.10 & -0.03 & 0.06 & 0.00 & -0.07 & 0.00 & 0.11 & 0.02 & -0.02 & 0.16 & & & & & & & \\
\hline Busy & 0.03 & 0.13 & 0.09 & 0.26 & -0.05 & -0.08 & -0.17 & 0.05 & 0.38 & -0.01 & 0.06 & 0.02 & 0.04 & -0.01 & & & & & & \\
\hline LAF & 0.10 & 0.09 & 0.09 & 0.36 & 0.06 & -0.15 & 0.09 & -0.09 & 0.16 & -0.03 & 0.09 & -0.05 & 0.06 & 0.10 & 0.27 & & & & & \\
\hline $\mathrm{AF}$ & -0.06 & -0.03 & -0.12 & -0.29 & -0.08 & 0.13 & -0.08 & 0.05 & -0.12 & 0.04 & -0.05 & 0.05 & -0.04 & -0.09 & -0.19 & -0.87 & & & & \\
\hline $\begin{array}{l}\text { Scaled } \\
\text { Fees }\end{array}$ & -0.11 & 0.15 & -0.05 & -0.64 & 0.07 & 0.04 & -0.07 & 0.15 & -0.21 & 0.18 & 0.11 & 0.01 & 0.25 & -0.03 & -0.03 & -0.26 & 0.26 & & & \\
\hline GC & 0.00 & 0.00 & 0.01 & 0.02 & -0.04 & -0.04 & -0.01 & -0.01 & 0.05 & 0.03 & 0.03 & -0.01 & 0.01 & -0.02 & 0.04 & 0.03 & -0.03 & -0.04 & & \\
\hline Fees & -0.03 & 0.50 & 0.15 & 0.64 & 0.07 & -0.18 & -0.01 & 0.03 & 0.20 & 0.16 & 0.25 & 0.03 & 0.18 & 0.11 & $\mathbf{0 . 3 0}$ & 0.32 & -0.24 & -0.01 & -0.04 & \\
\hline Delay & -0.11 & 0.01 & -0.04 & -0.16 & -0.01 & 0.01 & -0.09 & 0.03 & 0.03 & -0.03 & 0.06 & 0.07 & 0.02 & 0.02 & 0.07 & 0.01 & -0.02 & 0.22 & -0.01 & -0.01 \\
\hline
\end{tabular}

Panel B reports Pearson correlations based on the 580 combined company-year observations (n=214 unique firms) over Compustat fiscal years 2004-2006. Correlations in bold are different from zero at $\mathrm{p}<.05$ (two-tailed tests). Variable definitions are provided in the appendix. 


\subsection{Multivariate Results}

Table 3 presents the multivariate results of running Model 1 on our matched sample using heteroskedasticity-adjusted OLS. The dependent variable in Model 1 is the natural log of audit fees. The largest variance inflation factor for this model is 3.47 (on Roa), and the explanatory power of our model is high ( $0.8036 \mathrm{R}$ square) and consistent with other audit fee studies (Francis et al. 2005, Krishnan et al. 2011). Our variable of interest, IT, is negative and significant at the .0281 level, suggesting that companies with innovative IT have lower audit fees than their matched peers, and consistent with $\mathrm{H} 1$. The control variables are generally either consistent with prior audit fee studies or not significantly different from zero. Our results are both statistically and economically significant, as the -.084 coefficient on IT is effectively a reduction in audit fees of $\$ 143,548$, or $4.2 \%$ of the expected audit fees for a comparable company that is not recognized as having innovative IT.

Table 3. Multivariate Regression of the Natural Log of Audit Fees and IT Innovativeness

\begin{tabular}{|c|c|c|c|}
\hline & Estimate & t Value & $\operatorname{Pr}>|t|$ \\
\hline Intercept & 10.6248 & 44.4 & $<.0001$ \\
\hline IT & -0.0840 & -2.20 & 0.0281 \\
\hline Seg & 0.4608 & 11.73 & $<.0001$ \\
\hline $\mathrm{B} 4$ & 0.3745 & 2.11 & 0.0350 \\
\hline Size & 0.3745 & 18.68 & $<.0001$ \\
\hline MB & 0.0272 & 2.50 & 0.0128 \\
\hline Rec & -0.4959 & -2.90 & 0.0039 \\
\hline Roa & -0.4774 & -0.7 & 0.4819 \\
\hline RoaNeg & 0.1615 & 1.43 & 0.1536 \\
\hline Lev & -0.1674 & -0.94 & 0.3451 \\
\hline Spec & 0.0938 & 1.87 & 0.0624 \\
\hline Foreign & 0.2731 & 5.22 & $<.0001$ \\
\hline MW & -0.1394 & -1.19 & 0.2365 \\
\hline Restruc & 0.1248 & 2.31 & 0.0211 \\
\hline Merger & 0.0337 & 0.19 & 0.8507 \\
\hline Busy & 0.1245 & 2.05 & 0.0409 \\
\hline GC & -0.0007 & -0.01 & 0.9900 \\
\hline Sic Dummies & & Yes & \\
\hline Year Dummies & & Yes & \\
\hline R-square & & 0.8036 & \\
\hline
\end{tabular}

The regression presented is based off of 580 company-year observations from Compustat fiscal year 20042006 for 107 companies identified by Information Week as being innovative in information technology and 107 control companies. T-statistics presented are corrected for heteroskedasticity. Variable definitions are provided in the appendix.

Table 4 presents the multivariate results of running Model 2 on our matched sample using heteroskedasticity-adjusted OLS. The dependent variable is the natural $\log$ of audit delay. The largest variance inflation factor for this model is 5.41 (on LAF). The explanatory power of this model is also consistent with prior literature (Ashton et al. 1989). Our IT variable is negative and statistically significant at the 0.0236 level, suggesting that innovative IT companies have lower audit delay than their matched peers, and consistent with $\mathrm{H} 2$. The control variables in our model are generally consistent with prior literature or not significant. The economic significance of our findings is effectively a 2.29 day reduction in audit delay or a $3.6 \%$ reduction in the expected audit delay for a comparable company that is not recognized as innovative in IT. 
Table 4. Multivariate Regression of the Natural Log of Audit Delay and IT Innovativeness

\begin{tabular}{|c|c|c|c|}
\hline Parameter & Estimate & t Value & $\operatorname{Pr}>|t|$ \\
\hline Intercept & 4.335 & 15.78 & $<.0001$ \\
\hline IT & -0.0724 & -2.27 & 0.0236 \\
\hline Seg & 0.0227 & 0.56 & 0.5743 \\
\hline $\mathrm{B} 4$ & -0.0868 & -0.7 & 0.486 \\
\hline Size & -0.0321 & -1.65 & 0.0991 \\
\hline MB & -0.0125 & -1.18 & 0.2371 \\
\hline Rec & -0.1055 & -0.61 & 0.5413 \\
\hline Roa & 0.0675 & 0.1 & 0.9237 \\
\hline RoaNeg & 0.0984 & 0.68 & 0.4998 \\
\hline Lev & 0.1619 & 1.09 & 0.2746 \\
\hline Spec & -0.0644 & -1.55 & 0.1228 \\
\hline Foreign & 0.0883 & 1.41 & 0.1598 \\
\hline MW & 0.1223 & 0.9 & 0.3694 \\
\hline Restruc & -0.0352 & -1.04 & 0.2967 \\
\hline Merger & 0.0665 & 1.23 & 0.2181 \\
\hline Busy & 0.0962 & 2.04 & 0.0419 \\
\hline LAF & 0.0758 & 1.04 & 0.2982 \\
\hline $\mathrm{AF}$ & -0.0305 & -0.04 & 0.9656 \\
\hline GC & -0.0648 & -0.73 & 0.467 \\
\hline ScaledFees & 6.7877 & 2.56 & 0.0107 \\
\hline Sic Dummies & & Yes & \\
\hline Year Dummies & & Yes & \\
\hline R-square & & 0.1967 & \\
\hline
\end{tabular}

In an untabulated sensitivity analysis, we consider the impact of audit quality on our results using the Kothari et al. (2005) abnormal accruals model. Univariate results suggest that innovative IT companies have comparable audit quality to the matched control companies. In multivariate results, our research suggests that our Table 3 and Table 4 results are robust to the inclusion of abnormal accruals as a control variable. We conclude that the IT innovative firms achieve comparable audit quality at a lower cost and shorter audit lag.

\section{DISCUSSION AND CONCLUSION}

\subsection{Discussion}

Our study may be useful to companies and boards considering whether and how to invest funds in IT. Using a matched pair design, our research suggests that firms recognized as IT innovators pay lower audit fees and receive their audit reports in a timelier manner than the control firms. Our results are consistent with the idea that investments in IT can provide significant benefits for the firm. While prior research in the IT area has focused on the benefits on IT investment on business processes, supply chain efficiencies and administrative processes, our results suggest that the benefits of IT innovativeness extend beyond these traditional areas into the realm of auditing. With reductions in audit fees and duration of the audit, IT innovator firms pay less in terms of audit fees, and the efficiencies in reporting are associated with more relevance in reported information and higher information value. Presumably, the shorter audit period would also correspond to personnel-related benefits as there are fewer days company personnel must work a dual role to complete their regular tasks and accommodate auditor inquiries and requests. Future studies may choose to quantify some of the cost savings associated with a shorter report lag.

This study also has audit implications. Firms recognized for IT innovativeness have successfully implemented IT improvements. As such, auditors could expect for the firm's overall control risk to decrease, which would result in lower audit fees due to a less risky audit and more ability to rely on controls in place and thereby shift more testing to preliminary periods. 
Additionally, this paper contributes to the external validity and generalizability of Masli et al. 2010. Whereas Masli et al. (2010) analyze the benefits realizing from implementing technology specific to internal control systems and control risks, this study has more general focus on business risks and inherent risks, demonstrating a relationship between innovative IT companies and benefits. In our results, the specific IT implementation was not necessarily an internal control monitoring system in order to be associated with lower audit fees and timely audit reports.

\subsection{Limitations and Conclusions}

This study investigates the relationship between IT innovativeness and audit fees and report lag. Although the auditing literature is quite developed in both areas (fees and lag time), prior studies have not focused on the link between general IT innovation and these variables. Therefore, this study extends prior literature in a meaningful way by tying IT innovation to areas outside traditional auditing or IT research. Our results are consistent with the idea that IT innovation is associated with positive audit outcomes as evidenced by lower audit fees and shorter reporting periods.

Our study is not without limitations. First, our sample is limited to very large public firms that were identified on InformationWeek as being IT innovators. Whether the results of this study would extend to smaller firms is unknown. Second, we document an association between being recognized as an IT innovator and reduced audit fees and audit delay, but do not prove causality. There may be other exogenous variables correlated with IT innovativeness, audit fees and audit delay. We have attempted to control for such variables by using widely used and documented fee and delay models adapted from prior literature. However, it is impossible to rule out all other plausible explanations.

Our research adds to the literature demonstrating that good, innovative IT does matter. We encourage researchers to further add to this stream of research investigating the relationship between IT innovativeness and other accounting-related processes.

\section{AUTHOR INFORMATION}

Lorraine S. Lee is an associate professor of accounting at the Cameron School of Business, University of North Carolina Wilmington. She received her Ph.D. in business administration from the University of South Carolina. Her work has appeared in various journals, including Accounting, Organizations and Society, the International Journal of Accounting Information Systems, Internal Auditor, and the Journal of Corporate Accounting and Finance. E-mail: leel@uncw.edu

James Whitworth is an assistant professor in the School of Accountancy, teaching auditing and financial accounting. His research on audit report timelines has been published in Auditing: A Journal of Practice and Theory, and he received a best paper award from the 2012 Academy of Business Research Conference. Whitworth's research interests include auditing, financial accounting, corporate governance, audit committees, and earnings quality. Whitworth holds a CPA designation, a PhD in Accountancy from the University of Missouri.

Susan D. Hermanson is a Professor of Accounting and Dixon Hughes Goodman Faculty Fellow at the University of North Carolina Wilmington. She received her PhD in Accounting from Texas A\&M University. She has published over 50 refereed articles in such journals as Accounting Horizons, Issues in Accounting Education, Journal of Accounting Education, Internal Auditing, CPA Journal, Journal of Accountancy, Review of Business, Review of Business Information Systems, and Strategic Finance. E-mail: hermansons@uncw.edu (corresponding author) 


\section{REFERENCES}

Ashbaugh-Skaife, H., Collins, D., Kinnery, W. Lafond, R. (2009). The effect of SOX internal control deficiencies on firm risk and cost of equity. Journal of Accounting Research; 47 (1):1-43.

Ashton, R.H., illingham, J.J., Elliott, R.K. (1987). An empirical analysis of audit delay. Journal of Accounting Research; 25 (2): 275-292.

Ashton, R.H., Graul, P.R., Newton, J.D. (1989). Audit delay and the timeliness of corporate reporting. Contemporary Accounting Research; 5 (2): 657-673.

Bamber, E.M., Bamber, L.S., Schoderbeck, M.P. (1993). Audit structure and other determinants of audit report lag: An empirical analysis, Auditing: A Journal of Practice and Theory; 12 (1): 1-23.

Brazel, J.F., Dang, L. (2008). The effect of ERP system implementation on the management of earnings and earnings release dates. Journal of Information Systems; 22(2), 1-22.

Bronson, S.N., Hogan, C.E., Johnson, M.F., Ramesh K. (2011). The unintended consequences of PCAOB Auditing Standard Nos. 2 and 3 on reliability of preliminary earnings releases. Journal of Accounting and Economics;51 (1-2): 95-114.

Brunemeister, M.B., Glantz, J.G., Joshi, A. (2007). Sustain Your GRC Strategy with Continuous Controls Monitoring. SAP Insider; November - December, Available at: http://www.wispubs.com/sap_pdf/oct_nov_dec 07pdf2.pdf

Carcello, J. V., Hermanson, D. R., Neal, T. L., Riley, R. A. Board Characteristics and Audit Fees. (2002). Contemporary Accounting Research 2002; 19:365-384.

Casterella, J.R., Francis, J.R., Lewis, B.L, Walker, P.L. (2004). Auditor industry specialization, client bargaining power, and audit pricing. Auditing: A Journal of Practice and Theory; 23 (1): 123-140.

Committee of Sponsoring Organizations of the Treadway Commission (COSO). (2009). Internal ControlIntegrated Framework, Guidance on Monitoring Internal Control Systems; available at: http://www.coso.org/documents/COSO_Guidance_On_Monitoring_Intro_online1.pdf

Davenport, T.H. Process Innovation: Reengineering Work Through Information Technology. (1993). Boston, MA: Harvard Business School Press, 1993.

Dehning, B., Richardson, V.J., Zmud. R.W. (2007). The financial performance effects of IT-based supply chain management systems in manufacturing firms. Journal of Operations Management; 25 (4): 806-824.

Delaney, P.R., Epstein, B.J., Adler, J.R., Foran, M.F. (1997). GAAP 97: Interpretation and Application of Generally Accepted Accounting Principles, Wiley, United States.

Devaraj, S., Kohli, R. (2003). Performance impacts of information technology: Is actual usage the missing link? Management Science; 49:3, 273-289.

Dos Santos, B.L., Peffers, K. (1995). Rewards to investors in innovative information technology applications: First movers and early followers in ATMs. Organization Science; 6:3, 241-259.

Ettredge, M.L., Li,C., Sun,L. (2006). The impact of SOX section 404 internal control quality assessment on audit delay in the SOX era. Auditing: A Journal of Practice \& Theory; 25:2, 1-23.

Ferguson, A., Stokes, D. (2002). Brand name audit pricing, industry specialization and leadership premiums postBig 8 and Big 6 mergers. Contemporary Accounting Research; 19:77-110.

Francis, J.R., Reichelt, K, Wang,D. (2005). The pricing of national and city-specificreputations for industry expertise in the U.S. audit market. The Accounting Review; 80 (1): 113-136.

Francis, J.R., Simon, D.T. (1987). A test of audit pricing in the small-client segment of the U.S. Audit Market. The Accounting Review; 62 (January): 145-157.

Friedenberg, M. (2012). How to succeed in business: Award-winning IT Innovation," CIO; July 27. http://www.cio.com/article/711435/How to_Succeed_in_Business_Award_Winning_IT_Innovation, accessed 8/13/2012.

Hall, J. A. (2011) Information Technology Auditing and Assurance, $3^{\text {rd }}$ Edition. Mason, Ohio: South-Western Cengage Learning.

Hay, D.C., Knechel,W.R., Wong,N. (2006). Audit fees: A meta-analysis of the effect of supply and demand attributes. Contemporary Accounting Research; 23 (1): 141-191.

Henderson, B., Kobelsky,K., Richardson,V., Smith,R. (2010). The relevance of information technology expenditures. Journal of Information Systems; 24:2, 39-77.

Hitt, L.M., Brynjolfsson, E. (1996). Productivity, business profitability, and consumer surplus: Three different measures of information technology value. MIS Quarterly; 20:2, 121-142. 
InformationWeek. (2005) InformationWeek 500: Masters of Technology. InformationWeek, September 19; 57-67. Institute of Internal Auditors. (1978). Standards of Professional Practice of Internal Auditing. Orlando, Florida: Institute of Internal Auditors.

Klamm, B.,Weidenmier, M.W. (2009). SOX 404 reported internal control weaknesses: A test of COSO framework components and information technology. Journal of Information Systems; 23:2: 1-23.

Knechel, W.R., Payne J.L. (2001) Additional Evidence on Audit Report Lag. Auditing: A Journal of Practice and Theory; 20 (1): 137-146.

Kobelsky, K., Richardson, V., Smith, R., Zmud, R. (2008). Determinants and consequences of firm information technology budgets. The Accounting Review; 83(4): 957-995.

Kothari, S.P., Leone, J. and Wasley C. (2005). Performance matched discretionary accrual measures. Journal of Accounting and Economics; 39: 163-197.

Krishnan, J., Krishnan, J., Song, H. (2011). The effect of auditing standard no. 5 on audit fees. Auditing: A Journal of Practice \& Theory; 30:4, 1-27.

Krishnan, J., Yang, J.S. (2009). Recent trends in audit report and earnings announcement lags. Accounting Horizons; 23:3, 265-288.

Lambert, R., Leuz, C.,Verrecchi, R. (2007). Accounting information, disclosure, and the cost of capital. Journal of Accounting Research ; 45, 385-420.

Leventis, S., Weetman, P., Caramanis. C. (2005) Determinants of audit report lag: some evidence from the Athens stock exchange. International Journal of Auditing; 9 (1): 45-58.

Li, C., Peters, G., Richardson, V., Watson, M. (2012). The consequences of information technology control weaknesses on management information systems: The case of Sarbanes-Oxley internal control reports. MIS Quarterly; 36:1, 179-203.

Lyytinen, K., Rose, G.M. (2003). The disruptive nature of information technology innovations: The case of internet computing in systems development organizations. MIS Quarterly; 27:4, 557-595.

Masli, A., Peters, G., Richardson, V., Sanchez, J.M. (2010). Examining the potential benefits of internal control monitoring technology. The Accounting Review; 85:3, 1001-1034.

Masli, A., Richardson, V.J., Sanchez, J.M., Smith, R. (2011). The business value of IT: A synthesis and framework of archival research. Journal of Information Systems; 25:2, 81-116.

Newton, J.D., Ashton R.H. (1989). The association between audit technology and audit delay. Auditing: A Journal of Practice and Theory; 8 (2): 22-37.

O'Keefe, T.B., King, R.D., Gaver, K.M. (1994). Audit fees, industry specialization, and compliance with GAAS reporting standards. Auditing: A Journal of Practice and Theory; 13 (Fall): 41-55.

Palmrose, Z.V. (1986). Audit fees and auditor size: Further evidence. Journal of Accounting Research; 24 (Spring): 97-110

Rai, A., Patnayakuni, R., Patnayakuni, N. (2006). Firm performance impacts of digitally enabled supply chain integration capabilities. MIS Quarterly; 30:2, 225-246.

Sabherwal, R., Chan, Y.E. (2001). Alignment between business and IS strategies: A study of prospectors, analyzers, and defenders. Information Systems Research; 12:1, 11-33.

Sambamurthy, V., Bharadwaj, A., Grover V. (2003). Shaping agility through digital options: Reconceptualizing the role of information technology in contemporary firms. MIS Quarterly; 27(2): 237-263.

Schwartz, K.B., Soo, B.S. (1996). The association between auditor changes and reporting lags. Contemporary Accounting Research; 13 (1): 353-370.

Simunic, D.A. (1980). The pricing of audit services: Theory and evidence. Journal of Accounting Research; 18 (Spring): 161-190.

Swanson, E.B. (1994). Information systems innovation among organizations. Management Science; 40:9, 10691088.

Zuboff, S. (1988). In the Age of the Smart Machine: The Future of Work and Power. New York: Basic Books. 


\section{APPENDIX}

\begin{tabular}{|c|c|}
\hline Delay & The natural log of the difference between fiscal-year end date and audit report date for the company. \\
\hline Fees & The natural log of total audit fees reported by the company for the fiscal year. \\
\hline IT & $\begin{array}{l}\text { A dummy equal to one if the company is on Information Week's list of Most Innovative IT } \\
\text { companies, and zero otherwise. }\end{array}$ \\
\hline Seg & The natural $\log$ of the number of segments reported by the company. \\
\hline B4 & A dummy equal to one if the company's auditor is a Big 4 firm, and zero otherwise. \\
\hline Size & The natural log of total assets of the company (Compustat item AT). \\
\hline MB & $\begin{array}{l}\text { The ratio of the market value of equity (Compustat items PRCC_F * CSHO) divided by the book } \\
\text { value of equity (Compustat item CEQ). }\end{array}$ \\
\hline Rec & $\begin{array}{l}\text { The sum of the company's receivables and inventory (Compustat items RECT + INVT) divided by } \\
\text { total assets. }\end{array}$ \\
\hline Roa & Net income before extraordinary items (Compustat item IB) divided by total assets. \\
\hline RoaNeg & A dummy equal to one if Roa is negative, and zero otherwise. \\
\hline Lev & The company's total assets minus book value of equity, divided by total assets. \\
\hline Spec & $\begin{array}{l}\text { A dummy equal to one if the company reports special items (Compustat item SPI), and zero } \\
\text { otherwise. }\end{array}$ \\
\hline Foreign & $\begin{array}{l}\text { A dummy equal to one if the company has foreign operations (Compustat item FCA), and zero } \\
\text { otherwise. }\end{array}$ \\
\hline MW & A dummy equal to one if the company reports a material weakness, and zero otherwise. \\
\hline Restruc & $\begin{array}{l}\text { A dummy equal to one if the company took a restructuring charge (Compustat item RCP or RCEPS), } \\
\text { and zero otherwise. }\end{array}$ \\
\hline Merger & $\begin{array}{l}\text { A dummy equal to one if the company is engaged in a merger or acquisition (Compustat item AQP } \\
\text { or AQPEPS), and zero otherwise. }\end{array}$ \\
\hline Busy & A dummy equal to one if the company's fiscal-year-end is during December, and zero otherwise. \\
\hline LAF & A dummy equal to one if the company is a large accelerated filer, and zero otherwise. \\
\hline $\mathrm{AF}$ & A dummy equal to one if the company is an accelerated filer, and zero otherwise. \\
\hline ScaledFees & The ratio of audit fees paid to total assets. \\
\hline $\mathrm{GC}$ & dummy equal to one if the company received a going concern report, and zero otherwise. \\
\hline
\end{tabular}


NOTES 